\title{
Possibilities of Using Industrial Waste Heat for Heating Greenhouses in Northern Greece
}

\author{
John Vourdoubas ${ }^{1}$ \\ ${ }^{1}$ Mediterranean Agronomic Institute of Chania, Chania, Crete, Greece \\ Correspondence: John Vourdoubas, Mediterranean Agronomic Institute of Chania, Agrokipio, 73100, Chania, \\ Crete, Greece. Tel: 30-282-103-5020. Fax: 30-282-103-5001. E-mail: vourdoubas@maich.gr
}

Received: January 7, 2018

Accepted: February 6, $2018 \quad$ Online Published: March 15, 2018

doi:10.5539/jas.v10n4p116

URL: https://doi.org/10.5539/jas.v10n4p116

\begin{abstract}
The possibility of using the rejected heat from lignite-fired power plants for heating greenhouses in northern Greece has been examined. Although currently industrial waste heat is used for district heating in a few towns in Greece, its use in agriculture has not been reported so far. Due to many environmental and economic benefits symbiosis of industrial and agricultural activities is promoted in many countries. Greenhouses in northern Greece utilize mainly natural gas as heating fuel. However heat recovery from the existing power plants and its use in greenhouses could increase their energy efficiency and reduce the thermal pollution. It will also decrease the use of fossil fuels in greenhouses and the resulting carbon emissions as well. Their heating requirements have been estimated at $170 \mathrm{~W} / \mathrm{m}^{2}$ and the required hot water temperatures are $50-60{ }^{\circ} \mathrm{C}$ below the required water temperature in district heating systems, at $120^{\circ} \mathrm{C}$. Currently the price of heat sold in the district heating system in the town of Kozani is $0.0435 € / \mathrm{KWh}$, which is very attractive for heating greenhouses compared with other existing methods or fuels. It has been estimated that the heat recovery from the power plants at $70 \mathrm{MWth}$ could cover the heating needs of 41.2 ha of modern agricultural greenhouses in northern Greece. Recycling of industrial waste heat in greenhouses in northern Greece, apart from the resulting environmental benefits, will offer a competitive advantage, increasing the profitability of those enterprises.
\end{abstract}

Keywords: heating greenhouses, lignite, northern Greece, power stations, recycle, waste heat re-use

\section{Introduction}

The use of waste heat from industrial processes replacing fossil fuels in various applications results in improvements of energy efficiency and in reduced carbon emissions. Fossil fuel fired power plants produce large quantities of waste heat, which, when rejected in aquatic reservoirs, creates heat pollution. The possibility of re-using industrial waste heat at temperatures below $100{ }^{\circ} \mathrm{C}$ for district heating or for heating greenhouses could result in many economic and environmental benefits. The circular economy is currently promoted in the European Union, including materials and energy recycling. Industrial symbiosis with urban and agricultural activities has been paid a lot of attention in the last years and various applications worldwide have proved the resulting economic and environmental benefits as well as the improvements in overall sustainability.

\subsection{Waste Heat Re-Use and Industrial Symbiosis}

Viklund and Johansson (2014) have presented the technologies for utilization of industrial excess heat. The authors studied two different cases for excess heat recovery including delivery to a district heating system and heat-driven electricity generation. They concluded that excess heat recovery would result in reduced primary energy consumption and reduced $\mathrm{CO}_{2}$ emissions. The European Directive 2012/27 promotes energy efficiency, stating in article 14 that rejected industrial heat should be used either for district heating and cooling, or for covering heating needs in nearby located industries. Hung-Suck and Behera (2014) have presented methodological aspects of applying eco-efficiency indicators to industrial symbiosis networks. The authors proposed one economic indicator and three generally applicable environmental indicators including raw materials consumption, energy consumption and $\mathrm{CO}_{2}$ emissions. They also stated that in Ulsan Eco-industrial Park, South Korea, eco-efficiency has improved up to $28.7 \%$. Besides the evolution of seven IS networks comprising 21 companies resulted in an overall eco-efficiency enhancement of about $10 \%$. Beers and Biswas (2008) have studied a regional synergy approach to energy recovery in the Kwinana industrial area, Western Australia. The authors stated that Kwinana is recognized as a leading edge example in regional synergy 
development. However further synergies including energy utility synergies exist. The authors developed a methodology for energy recovery from industrial flue gases and its conversion to heat and electricity used in nearby applications. Ammar, Joyce, Norman, Wang, and Roskilly (2012) have reported on low grade thermal energy sources and uses from the process industry in the UK. The authors stated various efficient ways to use low grade heat rejected from the process industry, commenting on the limitations for low grade heat recovery. They concluded that organizational, financial and economic barriers should be removed in order to promote waste heat reuse in various applications.

\subsection{Waste Heat Use in District Heating Systems}

Karlopoulos, Pekopoulos, and Kakaras (2004) have published a report on district heating systems utilizing heat from lignite-fired power plants in Greece. The authors described the district heating systems in the city of Kozani in Northern Greece which is using hot water produced from the lignite power stations located $18 \mathrm{~km}$ away from the city. The installed thermal load was $70 \mathrm{MWth}$ and the outgoing-return temperatures were 120-65 ${ }^{\circ} \mathrm{C}$. The peak heating load in the city was covered with additional boilers using oil and LPG. Margaritis, Rakopoulos, Mylona, and Grammelis (2014) have studied the introduction of renewable energy sources in the district heating systems in Greece with reference to the towns of Kozani and Ptolemaida located in Northern Greece. Existing urban district heating systems in Greece are mainly utilizing waste heat from lignite power stations which are currently facing great challenges due to high pollution. The authors investigated three scenarios for replacing the waste heat from the lignite power stations including: a) The use of natural gas, b) The use of biomass in a CHP plant, and c) The use of a biomass boiler for heat production only. The authors concluded that the use of biomass for heat generation only is a good alternative to lignite power station waste heat for the district heating system in Kozani. Swithenbank, Finney, Chen, Yang, and Nolan (2013) have investigated waste heat usage in domestic, commercial and industrial buildings in the UK. The authors focused on waste heat produced from fossil-fuel power stations and waste incineration plants. They concluded that waste heat could be used in district heating systems which are not well developed in the UK, like in other EU countries. Pavlidis (2017) has reported on the experience from the use of district heating in the town of Kozani, northern Greece in the last sixteen years. The author stated that the public power company in Greece is providing 70 MWth to the municipality from the lignite power station of Ag. Dimitrios, which is going to be increased to 140 MWth. This heating load covers $95 \%$ of the annual needs for space heating and domestic hot water use in the town. He also stated that currently the price of heat sold to citizens, at $0.0435 € / \mathrm{KWh}$, is considered very attractive.

\subsection{Waste Heat Use in Heating Greenhouses}

A report on waste-to-energy based greenhouse heating has been published by Chinese, Meneghetti, and Nardin (2005). The authors studied the use of waste heat from a plant in north-eastern Italy for heating greenhouses. They concluded that coupling a greenhouse with a waste-to-energy plant, which was converting scraps of wood processing from the chair manufacturing industry, could represent an important step towards sustainable development. Andrews and Pearce (2011) have investigated the possibility of using waste heat from industrial processes for heating greenhouses in northern climates. The authors presented a case study for a tomato-producing greenhouse utilizing waste heat from a flat glass manufacturing plant. They concluded that using the industrial waste heat in the greenhouse was significantly more economic than a purely natural gas heating system. A report of an agricultural greenhouse heated with waste heat in the US has been presented by Manning and Mears (1983). The greenhouse with an area of 1.1 hectares was using condenser-discharged water from the Pennsylvania power station as its primary heat source. The authors estimated an overall energy consumption of $3200 \mathrm{MWh}$ per year per hectare while the water temperature in pipes placed on the floor was at $30{ }^{\circ} \mathrm{C}$ and the indoor air temperature was at $18{ }^{\circ} \mathrm{C}$. Waste heat reuse from a power plant in Germany for heating greenhouses has been reported by Bredenbeck (1992). The author stated that the cooling water from the 2700 MWel power plant, near Cologne, had an average temperature between $30-40{ }^{\circ} \mathrm{C}$ and the heating system was able to maintain an indoor air temperature at $22{ }^{\circ} \mathrm{C}$ even when the outside temperature was $-14{ }^{\circ} \mathrm{C}$. The total installed greenhouse area was approx. 5.3 hectares covered with single glass and thermal screens. Parker and Kiessling (2016) have implemented a study concerning low grade heat recycling obtaining synergies between waste heat and food production. The authors stated that heat recycling was a considerable enabler for food production. Waste heat resources are abundant, originating from thermal power stations as well as from other industrial processes. They concluded that the combination of waste heat with waste nutrient streams could have a positive impact on global food supply and sustainability. Leffler, Bradshaw, Groll, and Garimella (2012) have reported on alternative heat rejection methods in power plants. The authors stated that waste heat from those plants is commonly rejected in lakes or rivers, or through the use of cooling towers. They considered five 
alternative methods for recovering the rejected heat including cooling canals, open-water algae bioreactors, greenhouse heating, spray ponds and modified solar updraft towers. They concluded that three of the alternative methods examined including the algae bioreactor, greenhouse heating and the solar updraft tower generate secondary benefits. Maare (1992) has reported on the economical heat supply of greenhouse experiences presenting examples from Denmark. The author stated that the greenhouse farmers near Odense had formed a cooperative in order to use the waste heat from a nearby large combined heat and power station, with a district heat system, for heating their greenhouses. The greenhouse cooperative had 151 members who were able to keep the mean indoor air temperatures at $19^{\circ} \mathrm{C}$. The waste heat used in the greenhouses in Odense, Denmark resulted in annual savings of 65,000 tons of heavy oil.

\subsection{Use of Non-Conventional Heat Sources for Heating Greenhouses}

Vourdoubas (2016) has published a review on the use of sustainable energies in agricultural greenhouses. The author stated that energy requirements in modern greenhouses can be covered with sustainable energies including solar energy, biomass, geothermal energy, heat pumps, co-generation systems and reuse of waste heat. Papachristou et al. (2016) have reported on the geothermal energy use in Greece. The authors stated that low enthalpy geothermal fluids with temperatures at $60{ }^{\circ} \mathrm{C}$ are currently used for heating greenhouses in Greece. They described a tomato- and cucumber-producing modern hydroponic greenhouse located in Xanthi, Northern Greece, which utilized geothermal hot water at $60{ }^{\circ} \mathrm{C}$. Modern hydroponic greenhouses, producing vegetables, have been recently created in northern Greece, using natural gas for covering their energy needs: http://www.agritex.gr; https://www.wonderplant.gr/en/company. Since Greece currently imports tomatoes, the potential for the creation of more greenhouses is high. Gousgouriotis, Katsiyiannis, and Georgilakis (2007) have assessed the economic viability of biomass heating systems with reference to two agricultural greenhouses located in Chalkidiki, Northern Greece. The heating load of the greenhouses was $170 \mathrm{~W} / \mathrm{m}^{2}$ and the annual heat demand for a $5000 \mathrm{~m}^{2}$ greenhouse was $1519 \mathrm{MWh}$. The authors concluded that if the biomass price was low, at 50-75 $€ /$ ton, and a subsidy of $40 \%$ in the initial investment cost was offered, then the biomass heating system would be highly profitable. Vourdoubas (2015) has presented a case study of an agricultural greenhouse using solid biomass as heating fuel in Crete, Greece. The author stated that the annual heating needs of the greenhouse were $220 \mathrm{MWh}$ per $1000 \mathrm{~m}^{2}$ of covered area for keeping the indoor air temperature at $23{ }^{\circ} \mathrm{C}$. He also estimated that the use of heating energy had a share of $95.31 \%$ of the total energy consumption. Modern agricultural greenhouses, with a covered area of more than 10 hectares each, located in northern Greece, producing tomatoes and other vegetables with hydroponic technology, use natural gas for covering their heating needs. The fuel is used for co-generation of heat and power. Generated electricity is injected into the grid with attractive feed-in tariffs; the co-generated heat covers the heating needs of the greenhouses. An experimental investigation on using non-conventional energy sources including biogas, solar energy and ground source heat pumps for heating greenhouses has been reported by Esen et al. (2013). The authors stated that the plants in the experimental greenhouse required indoor temperature of $23{ }^{\circ} \mathrm{C}$. They concluded that the energy sources tested were successful in maintaining the desired temperature. An experimental and economic analysis of a horizontal ground source heat pump system used for space heating has been reported by Esen et al. (2006). The heating system was compared with conventional heating methods including electric resistance, fuel oil, liquid petrol gas, coal, oil and natural gas. The authors concluded that the ground source heat pump system was superior to all the conventional heating methods tested except the natural gas. A techno-economic comparison between a ground-coupled heat pump and an air-coupled heat pump used for space cooling has been reported by Esen et al. (2007). The authors have compared the cooling performance coefficients of the two heat pumps systems and they concluded that the ground source heat pump was economically preferable.

The objective of the current work is to investigate the possibility of using waste heat from the lignite-fired power plants in northern Greece for heating agricultural greenhouses, examining the technical feasibility and the economic viability as well as the resulting environmental benefits. Modern agricultural greenhouses in northern Greece require heating in order to increase the productivity of the crops and the quality of the produced products. On the other hand the reduction of fossil fuels use as well as carbon emissions is an important global goal of our societies in $21^{\text {st }}$ century. Symbiosis of industrial with agricultural activities in northern Greece would promote circular economy improving the overall sustainability.

Initially data from the existing district heating systems in northern Greece utilizing waste heat from the lignite-fired power plants were used. Secondly the heating needs of modern greenhouses in this area are examined as well as the operation of a hydroponic greenhouse in northern Greece heated with geothermal fluids. Industrial waste heat re-use in heating greenhouses was compared with other non-conventional heating methods, including the use of renewable energy sources, to indicate its advantages and drawbacks. Based on those 
findings an appraisal of the technical feasibility and the economic viability of heating greenhouses with waste heat from the power plants in northern Greece was made. Finally the environmental benefits of the symbiosis of industrial with agricultural activities in this area have been assessed.

\section{Use of Rejected Heat from Power Plants for District Heating in Northern Greece}

Currently rejected heat from lignite-fired power plants in Greece is used for district heating in a few cities located in the northern part of the country. The public power company usually offers hot water, at temperatures around $120{ }^{\circ} \mathrm{C}$, in municipalities located near to the existing power plants. This fact somehow offsets the high pollution in nearby urban areas created from the operation of the lignite power stations. Hot water is transported with well-insulated pipes to a central station and then it is distributed to various buildings in the town. The price of the rejected heat is low and therefore the municipality is able to offer low-cost heating and domestic hot water to the citizens. Use of waste heat from power plants results in improvements in their energy efficiency. It also eliminates the use of fossil fuels for heat generation as well as carbon emissions due to their use. Use of rejected heat from lignite power stations in agricultural activities has not been reported so far in Greece, although vegetable production greenhouses can utilize waste heat effectively for their space heating at low temperatures of $50-60{ }^{\circ} \mathrm{C}$.

\section{Heating Greenhouses with Non-Conventional Energy Sources}

\subsection{Heating Needs of Greenhouses in Northern Greece}

Agricultural greenhouses mainly producing vegetables located in Northern Greece require heating during their operation, particularly in the winter. Their heating needs depend on the type of construction, the crop cultivated and the local climate. Indicative values for their heating loads are approximately $170 \mathrm{~W} / \mathrm{m}^{2}$; for their annual energy they demand $304 \mathrm{MWh}$ per $1000 \mathrm{~m}^{2}$ (Gousgouriotis et al., 2007). The main fuels currently used for heating agricultural greenhouses in northern Greece are heating oil, natural gas with co-generation systems and low enthalpy geothermal energy. With the circulation of warm water at approximately $50{ }^{\circ} \mathrm{C}$ in plastic pipes placed on the ground among the plants, efficient heating of the greenhouse is obtained, maintaining the air indoor temperatures at $15-20{ }^{\circ} \mathrm{C}$ while the outdoor temperature is below zero. Use of natural gas with co-generation systems is currently a preferable method for heating in large modern greenhouses since the investment cost of the energy system is subsidized by the government. Additionally the electricity co-generated is sold to the grid operator with an attractive feed-in tariff guaranteed for many years. Finally exit gases produced containing $\mathrm{CO}_{2}$ are recycled inside the greenhouse, enriching its atmosphere and increasing the crop growth. Therefore the production of vegetables in modern greenhouses is combined with on-site electricity generation increasing the overall profitability of the enterprise. The geothermal hydroponic greenhouse reported by Papachristou et al. (2016) in northern Greece was operating with inlet water temperature at $60^{\circ} \mathrm{C}$ and outlet temperature at $30-35^{\circ} \mathrm{C}$. For heating eight (8) ha of the greenhouse, the flow rate of the geothermal fluid exceeded $500 \mathrm{M}^{3}$ per hour and the heating power was $13.81 \mathrm{MWth}$. It has previously been mentioned that the lignite power plant in Ag. Dimitrios is providing waste heat at $70 \mathrm{MW}$ th to the district heating system in Kozani. Assuming that each ha of a modern greenhouse in northern Greece requires for its heating 1.7 MWth (Gousgouriotis et al., 2007), it is concluded that the same amount of heat could cover the heating needs of 41.2 ha of greenhouses.

\subsection{Use of Non-Conventional Energy Sources}

Apart from fossil fuels or electricity generated from them, various non-conventional energy sources have been used for heating greenhouses. They include either renewable energy sources or very efficient energy systems like:
a) Use of geothermal energy,
b) Use of biomass,
c) Use of heat produced from co-generation systems fired either by fossil fuels or with biomass, and
d) Waste heat re-use.

The main characteristics of the non-conventional energy sources used for heating greenhouses are as follows:

a) The technology used is rather simple and their technical feasibility is well proven,

b) The systems are mature and cost-effective,

c) They have significant environmental benefits consisting of a more sustainable approach for heating greenhouses, 
d) Their use in greenhouses could be combined with electricity generation,

e) In the case of geothermal energy, biomass and waste heat, the availability of the energy source is a prerequisite for their use,

f) They utilize local and endogenous energy sources,

g) In the case of waste heat re-use, rejected heat at low temperatures of $50-60{ }^{\circ} \mathrm{C}$, which is difficult to be used in other applications, can be used in heating greenhouses, and

h) In general, their use is promoted and subsidized by the public sector.

However in many cases there are various barriers hindering their use which should be removed. In recent years European policies are targeting in the promotion of the circular economy. This fact results in the symbiosis of industrial with urban and agricultural activities since the recycling of matter and energy improves the overall sustainability, reduces carbon emissions and mitigates climate change. Under these circumstances the industrial waste heat re-use for heating greenhouses consists of a challenging alternative to traditional heating methods.

\section{Possibility of Using the Rejected Heat from Lignite-Fired Power Plants in Northern Greece for Heating Greenhouses}

The possibility of using rejected heat from lignite power plants in northern Greece in order to heat greenhouses is assessed, examining both their technical feasibility and their economic viability. Experience for utilizing waste heat already exists in the area since the power plants provide hot water at $120^{\circ} \mathrm{C}$ to the nearby municipalities in order to operate their district heating systems.

\subsection{Technical Feasibility}

The infrastructure for transporting hot water from the power plant to the greenhouses includes the construction of a well-insulated pipe placed under the ground coupled with a pumping system. The hot water temperature needed is approximately $50-55^{\circ} \mathrm{C}$ while the return temperature would be approximately $30-35{ }^{\circ} \mathrm{C}$. Incoming hot water will be circulated inside plastic pipes placed on the ground among the plants and heat will be transferred to the soil and to the air. In the case of a hydroponic culture the water solution as well as the air will be heated. The required temperatures are well below the water temperatures needed in the existing district heating system in Kozani town. Assuming a $20{ }^{\circ} \mathrm{C}$ drop in the water temperature inside the greenhouse and heating loads of 1700 KWth per hectare (Gousgourgiotis et al., 2007), the hot water flow rate should be $73.18 \mathrm{M}^{3}$ per hour per hectare. This can be compared with a flow rate of hot water at $2300 \mathrm{M}^{3}$ per hour (140 MWth) (Pavlidis, 2017) in the district heating system in Kozani. An additional boiler for covering the heating peaks in the greenhouse, fueled with natural gas, oil or solid biomass, and possibly a well-insulated heat storage tank are required. The construction of the heat transport system, from the power plant to the greenhouse, does not present major technical difficulties and it is rather similar to a system transporting warm geothermal fluids from the production to the consumption site.

\subsection{Economic Viability}

The cost of conventional fuels, including oil, electricity and natural gas, used in heating greenhouses in northern Greece is presented in Table 1. Additionally to the fuel cost the installation cost of the heating system should be estimated and taken into account in order to calculate the total heating cost. For high efficiency heating systems like heat pumps, the installation cost is significantly higher. In the case that industrial waste heat is utilized for heating greenhouses, the investment in a heat production system is not needed. Therefore there are no costs related to depreciation and annual maintenance of the heating systems. Comparison with the current price of heating in the district heating system in Kozani, which is $0.0435 € / \mathrm{KWh}$ (Pavlidis, 2017), indicates that the use of warm water from the lignite power plant for heating greenhouses is more economical than the use of conventional fuels. Natural gas has many advantages compared to oil since it does not need storage, it can be used for co-generation of heat and power and it is a less polluting fuel. 
Table 1. Fuel costs for heating greenhouses with conventional fuels in Greece

\begin{tabular}{lll}
\hline Fuel & Efficiency of the heating system $(\%)$ & Price $(€ / \mathrm{KWh})$ \\
\hline Fuel oil & 90 & 0.043 \\
Heating oil & 90 & 0.138 \\
Electricity & 100 & 0.100 \\
Heat pumps & $200-250$ & $0.04-0.05$ \\
Natural gas (only for heating) $^{*}$ & 95 & 0.052 \\
\hline
\end{tabular}

Note. ${ }^{*}$ Current price of natural gas in Greece.

Source: Vourdoubas (2015).

\section{Environmental Impacts}

Use of various fossil or non-fossil fuels for heating greenhouses results in environmental degradation depending on the type of fuel used. Use of oil, natural gas or electricity generated by fossil fuels results in carbon emissions. Use of solid biomass results in carbon emissions but due to the photosynthesis process it is assumed that net carbon emissions are zero. Additionally particulate matter is emitted with the flue gases. Use of geothermal fluids is usually combined with the rejection of dissolved salts or gases contained in the geothermal fluids. Industrial waste heat reuse has minimum environmental impacts if the hot liquid stream is cooling water. In the case that cooling water is reused instead of being rejected to a reservoir, apart from the energy gains, thermal pollution is avoided. At the same time the energy efficiency in the industry is increased. Therefore the environmental impacts due to the use of rejected heat from the lignite power plants for heating greenhouses in northern Greece include:

a) Decrease of $\mathrm{CO}_{2}$ emissions due to fossil fuels savings,

b) Decrease of thermal pollution due to hot water disposal, and

c) Increase of energy efficiency in the power plants.

The environmental impacts due to the use of various fuels in heating greenhouses are presented in Table 2 .

Table 2. Environmental impacts due to the use of various fuels in heating greenhouses

\begin{tabular}{ll}
\hline Fuel & Pollutants \\
\hline Oil & Greenhouse gases, nitrogen and sulfur oxides \\
Natural gas & Greenhouse gases, nitrogen and sulfur oxides \\
Electricity & Pollutants depend on the fuels used for electricity generation \\
Solid biomass & Particulate matter, nitrogen and sulfur oxides \\
Geothermal energy & Depends on the matter mixed with the geothermal fluids, dissolved salts \\
Industrial waste heat & Absence of pollutants, reduction of thermal pollution created by the rejected heat \\
\hline
\end{tabular}

\section{Discussion and Conclusions}

Lignite-fired power plants in northern Greece emit large amounts of waste heat which is currently partly utilized for district heating in nearby located towns. In recent years various modern greenhouses producing mainly vegetables have been constructed in northern Greece while further growth is foreseen. Climate conditions in this area necessitate the heating of the greenhouses during the winter which results in higher crops productivity. Natural gas from the central piping system is the preferable fuel for heating the greenhouses combined with co-generation of heat and power. If a geothermal spring is located near the greenhouse, geothermal energy is an attractive option for its heating. Low enthalpy geothermal energy with ground source heat pumps is an alternative heating and cooling option. Agricultural and forest biomass could also be used as a renewable fuel for heating them. Other renewable energy sources which could be used for heating greenhouses are solar thermal energy and biogas produced from a nearby landfill. Another option for heating greenhouses located near the power plants is the use of the rejected heat in the cooling water streams which should be considered as a cheap and environmentally friendly energy source. Water temperatures required for heating them are relatively low at approximately $50-60{ }^{\circ} \mathrm{C}$ compared to $120{ }^{\circ} \mathrm{C}$ used for district heating. Hot water transport can be achieved with well-insulated pipes and the temperature drop across the pipe is low. Compared with other fossil or renewable 
fuels used in heating greenhouses, the use of the rejected heat from the existing power plants in northern Greece has many environmental and economic benefits. Among them it reduces the use of fossil fuels imported and the emissions of greenhouse gases due to their use. It could be combined with the use of energy saving techniques and technologies in modern greenhouses improving their overall energy behavior and increasing their environmental sustainability. Current European policies are targeting in the creation of nearly zero energy buildings. In the same way the creation of nearly zero energy agricultural greenhouses with nearly zero carbon emissions should be promoted in the near future. Taking into account the current price of energy recovered from the power plants and sold in the district heating system in Kozani, at $0.0435 € / \mathrm{KWh}$, it is concluded that the use of rejected heat for heating greenhouses is economically attractive and profitable. It has been assumed that for the climate conditions in northern Greece the heating requirements of a modern greenhouse are 1.7 MWth per ha It has been calculated that industrial heat recovery at $70 \mathrm{MWth}$, like in the district heating system in Kozani, covers the heating needs of 41.2 ha greenhouses. Recycling of waste heat from the power plants and its use in greenhouses, due to the low heating cost, will offer a competitive advantage to modern greenhouse growers promoting these investments in northern Greece. Since industrial waste heat, despite being a well proven technology, has not been used so far for heating greenhouses in Greece, an innovative demonstrative greenhouse should be created in this area. Further work should be focused on the study of greenhouse heating from existing lignite power plants in other Greek territories like in Megalopolis, Peloponissos. Current work indicates that symbiosis of industrial with agricultural activities in northern Greece will promote the circular economy, resulting in economic and environmental benefits. Therefore it should be supported from the government through various initiatives.

\section{References}

Ammar, Y., Joyce, S., Norman, R., Wang, Y., \& Roskilly, A. (2012). Low grade thermal energy sources and uses from the process industry in the UK. Applied Energy, 89, 3-20. https://doi.org/10.1016/j.enconman.2008. 06.008

Andrews, R., \& Pearce, J. M. (2011). Environmental and economic assessment of a greenhouse waste heat exchange. Journal of Cleaner Production, 19, 1446-1454. https://doi.org/10.1016/j.jclepro.2011.04.016

Beers, D. V., \& Biswas, W. K. (2008). A regional synergy approach to energy recovery: The case of Kwinana industrial area, Western Australia. Energy Conversion and Management, 49, 3051-3062. https://doi.org /10.1016/j.enconman.2008.06.008

Bredenbeck, H. (1992). The use of waste heat from a power plant for greenhouse heating in commercial application in Germany. Acta Horticulturae, 312, 29-35. https://doi.org/10.17660/ActaHortic.1992.312.3

Chinese, D., Meneghetti, A., \& Nardin, G. (2005). Waste to energy based greenhouse heating: Exploring viability conditions through optimization models. Renewable Energy, 30, 1573-1586. https://doi.org/10.1016/ j.renene.2004.11.008

Esen, H., Inalli, M., \& Esen, M. (2006). Techno-economic appraisal of a ground source heat pump system for a heating season in Eastern Turkey. Energy Conversion and Management, 47(9), 1281-1297. https://doi.org/10.1016/j.enconman.2005.06.024

Esen, H., Inalli, M., \& Esen, M. (2007). A techno-economic comparison of ground-coupled and air-coupled heat pump system for space cooling. Building and Environment, 42(5), 1955-1965. https://doi.org/10.1016/ j.buildenv.2006.04.007

Esen, M., \& Yuksel, T. (2013). Experimental evaluation of using various renewable energy sources for heating a greenhouse. Energy and Buildings, 65, 340-351. https://doi.org/10.1016/j.enbuild.2013.06.018

European Directive 2012/27. (2012). Directive 2012/27/EU of 25 October 2012 on energy efficiency, amending Directives 2009/125/EC and 2010/30/EU and repealing Directives 2004/8/EC and 2006/32/EC.

Gousgouriotis, I. J., Katsigiannis, Y. A., \& Georgilakis, P. S. (2007). Economic evaluation of biomass heating systems: A case of greenhouses in northern Greece. Operational Research. An International Journal, 7(1), 37-58. https://doi.org/10.1007/BF02941187

Hung-Suck, P., \& Behera, S. K. (2014). Methodological aspects of applying eco-efficiency indicators to industrial symbiosis networks. Journal of Cleaner Production, 64, 478-485. https://doi.org/10.1016/j.jclepro.2013. 08.032 
Karlopoulos, E., Pekopoulos, D., \& Kakaras, E. (2004). District heating systems from lignite-fired power plants-Ten years experience in Greece. Proceedings of the International Workshop on Promotion of CHP/Tri-generation and Collaborative Potentials in Chinese Market. Hangzhou, China, April 26-28, 2004.

Leffler, R. A., Bradshaw, C. R., Groll, E. A., \& Garimella, S. V. (2012). Alternative Heat Rejection Methods for Power Plants. CTRC, Research Publications, Paper 159. https://doi.org/10.1016/j.apenergy.2011.10.023

Maare, O. (1992). Economical Heat Supply of Greenhouses Experiences from Denmark. Acta Horticulturae, 312, 37-44. https://doi.org/10.17660/ActaHortic.1992.312.4

Manning, T. O., \& Mears, D. R. (1983). Engineering performance of a 1.1 hectare waste-heated greenhouse. Paper presented in the summer meeting of the American Society of Agricultural Engineers, Montana State University, Bozeman, Montana, June 26-29, 1983.

Margaritis, N., Rakopoulos, D., Mylona, E., \& Grammelis, P. (2014). Introduction of renewable energy sources in the district heating system of Greece. International Journal of Sustainable Energy Planning and Management, 4, 43-56. https://doi.org/10.5278/ijsepm.2014.4.5

Papachristou, M., Mendrinos, D., Dalampakis, P., Arvanitis, A., Karytsas, C., \& Andritsos, N. (2016). Geothermal energy use, Country update for Greece (pp. 1-14). European Geothermal Congress 2016, Strasboutg, France, September 19-24, 2016.

Parker, T., \& Kiessling, A. (2016). Low grade heat recycling for system synergies between waste heat and food production: A case study at the European spallation source. Energy Science and Engineering, 4(2), 153-165. https://doi.org/10.1002/ese3.113

Pavlidis, G. (2017). Municipal company in Kozani (ppt presentation for the district heating in Kozani the last 16 years). Retrieved December 22, 2017 from http://www.deyakozanis.gr/wp-content/uploads/2010/04/ deyak.ppt

Swithenbank, J., Finney, K. N., Chen, Q., Yang, Y. B., \& Nolan, A. (2013). Waste heat usage. Applied Thermal Engineering, 60, 430-440. https://doi.org/10.1016/j.applthermaleng.2012.10.038

Viklund, S. B., \& Johansson, M. (2014). Technologies for utilization of industrial excess heat: Potentials for energy recovery and $\mathrm{CO}_{2}$ emission reduction. Energy Conversion and Management, 77, 369-379. https://doi.org/10.1016/j.enconman.2013.09.052

Vourdoubas, J. (2015). Overview of heating greenhouses with renewable energy sources. A case study in Crete-Greece. Journal of agricultural and Environmental Sciences, 4(1), 70-76. https://doi.org/10.15640/ jaes.v4n1a9

Vourdoubas, J. (2016). Overview of the use of sustainable energies in agricultural greenhouses. Journal of Agricultural Sciences, 8(3), 36-43. https://doi.org/10.5539/jas.v8n3p36

\section{Copyrights}

Copyright for this article is retained by the author(s), with first publication rights granted to the journal.

This is an open-access article distributed under the terms and conditions of the Creative Commons Attribution license (http://creativecommons.org/licenses/by/4.0/). 